\title{
The relationship between biochemical parameters, interleukin- 6 and ovarian morphology in polycystic ovary syndrome
}

\author{
Polikistik over sendromunda biyokimyasal parametreler, interlökin-6 ve over morfolojisi \\ arasındaki ilişki
}

\author{
Mehmet Sühha Bostanc1 ${ }^{1}$, Merih Bayram², Faika Ceylan Sevinç ${ }^{3}$, Hatice Paşaoğlư ${ }^{4}$, Şehri Elbeg ${ }^{4}$
}

\begin{abstract}
Objectives: The aim of this study is to investigate relationships between biochemical parameters and interleukin-6 according to the ovarian morphology in polycystic ovary syndrome (PCOS).

Materials and methods: Total of 85 patients with PCOS were divided into three groups according to the ultrasonographic examination of the ovaries; group 1 (with no polycystic image at any of the ovaries, $n=22$ ), group 2 (with polycystic image at only one ovary, $n=41$ ), and group 3 (with polycystic image at both of the ovaries, $n=22$ ). Serum interleukin 6 (IL-6), hormone levels, and homeostasis model assessment-insulin resistance (HOMA-IR) were measured.
\end{abstract}

Results: The mean serum IL-6 levels for groups 1, 2 and 3 were $14.65 \pm 6.18 \mathrm{pg} / \mathrm{mL}, 16.22 \pm 6.55 \mathrm{pg} / \mathrm{mL}$, and $14: 53 \pm 7.32 \mathrm{pg} / \mathrm{mL}$, respectively. There was no statically difference between three groups for serum IL-6 levels $(p>0.05)$. For metabolic profile, the mean of HOMA-IR was $3.09 \pm 1.56$ for group 2 and this was significantly lower than other groups $(p<0.05)$.

Conclusions: There were no difference in hormonal and inflammatory markers according to the ovarian morphology in PCOS patients based on data derived form our study. J Clin Exp Invest 2012; 3(3): 307-312

Key words: PCOS, interleukin-6, ovarian morphology.

\section{INTRODUCTION}

Polycystic ovary syndrome (PCOS) is a common endocrine disorder affecting about $6 \%$ of women of reproductive age which is characterized by both gynecological and endocrine symptoms, including chronic anovulation and hyperandrogenism. ${ }^{1}$ In 2003, the European Society for Human Reproduc-

\section{ÖZET}

Amaç: Bu çalışmanın amacı polikistik over sendromunda (PKOS) biyokimyasal parametreler ve interleukin-6 ile over morfolojisi ilişkisini değerlendirmektir.

Gereç ve yöntem: PKOS tanısı almış 85 hasta overlerin ultrasonografik değerlendirmesine göre; grup 1 ( polikistik görünümü olmayan, $n=22$ ), grup 2 (bir overde polikistik görüntüsü olan, $n=41$ ) ve grup 3 (her iki overde polikistik görüntüsü olan, $n=22$ ) olmak üzere üç gruba ayrıldı. Hastaların serum interlökin 6 (IL-6), hormone düzeyleri ve homeostasis model assessment-insulin rezistans (HOMA-IR) değerleri ölçüldü.

Bulgular: Serum IL-6 seviyeleri değerlendirildiğinde, ortalama değerler gruplar için sırasıyla $14.65 \pm 6.18 \mathrm{pg} / \mathrm{mL}$, $16.22 \pm 6.55 \mathrm{pg} / \mathrm{mL}$ ve $14.53 \pm 7.32 \mathrm{pg} / \mathrm{mL}$ olarak bulundu. Serum IL-6 düzeyleri için üç grup arasında istatistiksel olarak anlamlı bir fark yoktu ( $p>0.05)$. Metabolik profiling değerlendirmesinde ise HOMA-IR değeri grup 2 de $3,09 \pm 1,56$ bulundu ve diğer gruplara göre anlamlı düzeyde düşüktü $(p<0.05)$.

Sonuç: Çalışmamız verilerine dayanarak, PKOS hastaları için over morfolojisine göre hormonal ve inflamatuvar belirteçler arasında fark yoktu.

Anahtar kelimeler: PKOS, interlökin-6, over morfolojisi.

tion and Embryology (ESHRE) and the American Society for Reproductive Medicine (ASRM) revised the definition of PCOS 1; the syndrome is now defined as the presence of any two of the following three criteria: polycystic ovaries, oligo/anovulation and/or clinical or biochemical evidence of hyperandrogenism. ${ }^{1}$ In addition to the reproductive abnor-

\section{${ }^{1}$ Department of Obstetrics and Gynecology, Sakarya Education and Research Hospital, Sakarya, Turkey \\ ${ }^{2}$ Department of Obstetrics and Gynecology, Faculty of Medicine, Gazi University, Ankara, Turkey \\ ${ }^{3}$ Department of Obstetrics and Gynecology, Faculty of Medicine, Baskent University, Konya, Turkey ${ }^{4}$ Department of Biochemistry, Faculty of Medicine, Gazi University, Ankara, Turkey}

Correspondence: Mehmet Sühha Bostanci,

Sakarya Eğitim ve Araştırma Hastanesi Kadın Hastalıkları ve Doğum Kliniği, Sakarya Email: msuhha@gmail.com 
malities, a significant proportion of PCOS women suffer from obesity, insulin resistance and features of the metabolic syndrome. ${ }^{2}$ Other factors that independently increase cardiovascular risk, such as obesity, arterial hypertension, dyslipidaemia and clotting disorders, may coexist in women with PCOS. ${ }^{3,4}$

Inflammatory processes, particularly increased proinflammatory cytokine production and activation of immune system, are associated with obesity, and have been implicated in the pathophysiology of atherosclerosis, the metabolic syndrome, insulin resistance, and diabetes mellitus. ${ }^{5}$ There is accumulating evidence indicating chronic low-grade inflammation in PCOS, including increased levels of C-reactive protein (CRP), increased leukocyte numbers, and increased pro-inflammatory cytokines. 6 Human interleukin 6 (IL-6) is a 184 AA polypeptide with potential $\mathrm{O}$ - and $\mathrm{N}$-glycosylation sites and a significant homology with G-CSF. It is produced by various cells, including $T$ and $B$ cells, monocytes, fibroblasts, endothelial cells, mesangial cells and several tumor cells. IL-6 regulates the growth and differentiation of various cell types with major activities on the immune system, hematopoiesis and inflammation. ${ }^{7}$ The elevation of serum IL-6 precedes that of acute phase proteins, e.g., in a postoperative phenomenon and may thus be a sensitive early parameter to investigate inflammatory conditions. IL-6 signaling molecule is associated with hyperandrogenism and PCOS, or influence hyperandrogenic phenotypic traits. ${ }^{8}$ The adipose tissue plays common role in the relationship between cytokines and insulin resistance. Inflammatory cytokines might induce insulin resistance by direct actions on insulin- signaling post receptor molecules or by inducing central obesity through activation of the hypothalamic- pituitary-adrenal axis. ${ }^{9}$

Polycystic ovary morphology is a cardinal feature of PCOS defined as irregular menses and hyperandrogenism. ${ }^{10,11}$ But the presence of polycystic ovary morphology does not enough for diagnosis of PCOS and may be seen with normal women. ${ }^{1,12}$ On the other hand there is not adequate information about the characteristics of inflammation marker of PCOS patients with normal ovarian morphology. The aim of this study is to estimate relationship with the biochemical parameters and interleukin- 6 according to the ovarian morphology in PCOS.

\section{MATERIALS AND METHODS}

\section{Study subjects}

Total of 85 non-smoking subjects with PCOS who were admitted to the department of gynecology and obstetrics of Faculty of Medicine of Kirikkale University were enrolled in this study. They were divided according to the ultrasonographic examination of the ovaries into three groups; group 1 (with no polycystic image at any of the ovaries), group 2 (with polycystic image at only one ovary), and group 3 (with polycystic image at both of the ovaries). All women were euthyroid and not taking any medication or hormones for six months (including oral contraceptive agents) known to affect sex hormones or carbohydrate metabolism. The diagnosis of PCOS was made on the basis of the revised 2003 Rotterdam ESHRE/ASRM diagnostic criteria ${ }^{1}$, women with PCOS meet two of the following three criteria after exclusion of other etiologies (pituitary insufficiency, persistent hyperprolactinemia, congenital adrenal hyperplasia): (a) oligomenorrhea or anovulation; (b) clinical and/or biochemical signs of hyperandrogenism; (c) polycystic ovaries.

Age, height, body weight, waist circumference and systolic and diastolic blood pressure were recorded. Waist circumference was taken midway between the inferior margin of the last rib and the crest of the ileum in the horizontal plane, while in an upright position. Body mass index (BMI) was calculated for all groups as body weight $(\mathrm{kg})$ divided by body height squared $\left(\mathrm{m}^{2}\right)$. Waist/Hip ratio (WHR) was calculated as waist circumference divided by hip circumference. Ferriman-Gallwey score $\geq 7$ was used for grading hirsutism. ${ }^{13}$

\section{Radiologic procedures}

Ultrasonographic examinations were performed in the early follicular phase (days $1 \pm 3$ ) of the menstrual cycle, when the ovaries are relatively quiescent by a single operator following the criteria of the Rotterdam ESHRE/ASRM Consensus. ${ }^{1}$ Transabdominal ultrasonographic examination was performed on each patient by using linear-array real time ultrasound with a 2.0-MHz transducer (GE LOGIQ 9 Milwaukee, USA).

\section{Sample collection}

Blood was drawn for determination of basal endocrinological and immunological parameters between 9:00 and 10:00. Fasting blood samples were taken from the antecubital vein at rest in the supine position at the morning. Blood was immediately transferred into ice-chilled glass tubes containing disodium EDTA (1 mg/ml) and centrifuged $1600 \mathrm{~g}$, for $15 \mathrm{~min}$ at $4^{\circ} \mathrm{C}$. Serum samples were frozen and stored at $-70^{\circ} \mathrm{C}$ until assayed. 


\section{Biochemical procedures}

The fasting blood sample was analyzed for serum thyroid stimulating hormone (TSH), free triiodothyronine (FT3), free thyroxine (FT4), follicle stimulating hormone $(\mathrm{FSH})$, luteinizing hormone $(\mathrm{LH})$, estradiol (E2), androstenedione (AS), dehydroepiandrosterone-sulphate (DHEAS), total testosterone (Ttes) and free testosterone (Ftes) on day 2 or 3 of menstrual cycle while serum progesterone was measured on day 21.

Serum IL-6 levels were measured by ELISA (Human IL-6 Immunoassay Kit, KHC0061, BioSource International, USA) as described previously. ${ }^{14}$

After $12 \mathrm{~h}$ of fasting, serum glucose, total cholesterol, triglycerides, high density lipoprotein (HDL) and low density lipoprotein (LDL) concentrations were determined using an autoanalyzer into the standard laboratory measurements. Serum insulin was measured by immunoradiometric assay. The estimate of insulin resistance by the homeostasis model assessment (HOMA-IR) was calculated with the following formula; fasting serum insulin $(\mu \mathrm{IU} /$ $\mathrm{mL}$ ) $x$ fasting serum glucose $(\mathrm{mmol} / \mathrm{L}) \div 22,5 .{ }^{15}$ The HOMA-IR value was given as mean $\pm S D$, and appraised the values $>2,5$ as an insulin resistant state and the values $<2,5$ as an insulin sensitive state.

Glucose tolerance was evaluated using $75 \mathrm{~g}$ Oral Glucose Tolarance Test (OGTT). Abnormal plasma OGTT was classified according to the American Diabetes Association (ADA) 2003 criteria ${ }^{16}$ as follows: (i) impaired fasting glucose (IFG), that is, fasting blood glucose (FBG) $\geq 100$ and $<126 \mathrm{mg} /$ $\mathrm{dL}$, (ii) impaired glucose tolerance test (IGT), that is, 2-hr glucose $\geq 140$ and $<200 \mathrm{mg} / \mathrm{dL}$, and (iii) type $2 \mathrm{DM}$, that is, FBG $\geq 126 \mathrm{mg} / \mathrm{dL}$ or 2 -hr glucose $\geq 200 \mathrm{mg} / \mathrm{dL}$. All subjects gave them informed consent to participate in the present study.

\section{Statistical analysis}

All analyses were performed with the SPSS statistical package version 10.0. Statistical significance was set as $5 \%$. All results are reported as mean $+/$ standard deviation. All parameters of three groups were compared each other with Mann- Whitney U Test. In statistically different parameters between groups, the difference producing group was determined by Bonferoni correction.

\section{RESULTS}

The mean age of groups were $21.27 \pm 3.95$ years for group 1, 24.46 \pm 5.29 years for group 2, and $24.52 \pm 6.90$ years for group3 respectively. There was not statically difference between groups for age $(p>0.05)$. The anthropometric characteristics of groups are listed in Table 1. Upon comparing both groups of patients; BMI, WHR were significantly increased in group $2(p=0.07)$. For metabolic profile, the mean of HOMA-IR was $3.09 \pm 1.56$ for group 2 and significantly low from other groups $(p=0.01)$. As OGTT determined mean value for group 2 was $127.32 \pm 30.04 \mathrm{mg} / \mathrm{dL}$ and statically high from group 1 and $3(p=0.05)$. The value of OGTT was $102.18 \pm 22.07 \mathrm{mg} / \mathrm{dL}$ for group 1 and $97.55 \pm 25.28$ for group 3. The metabolic characteristics of groups are listed in Table 2.

The outcomes of the Mann- Whitney $U$ Test determined that there was statistically no difference between groups for FSH, E2, LH, TSH, FT3, FT4, DHEAS, As, Ftes, Ttes, progesterone on 21 th day of menstrual cycle. When we determined the interleukin-6 (IL-6) levels of the groups the mean for group 1 was $14.65 \pm 6.18 \mathrm{pg} / \mathrm{mL}$. The mean value for group 2 was $16.22 \pm 6.55 \mathrm{pg} / \mathrm{mL}$ and $14.53 \pm 7.32$ for group 3 . There was no statically difference between three groups for IL-6 ( $>00.05)$. The hormonal characteristics and IL-6 levels of groups are listed in Table 3. According to Bonferoni correction, the difference producing groups for BMI, WHR, FGS, HOMA-IR and for OGTT were determined as group 2 according to the others.

Table 1. The anthropometric characteristics of groups.

\begin{tabular}{lllll}
\hline & Group 1 $(\mathrm{n}=22)$ & Group 2 $(\mathrm{n}=41)$ & Group 3 $(\mathrm{n}=22)$ & P value \\
\hline Age (years) & $21.27 \pm 3.95$ & $24.46 \pm 5.29$ & $24.52 \pm 6.90$ & 0.072 \\
BMI $\left(\mathrm{kg} / \mathrm{m}^{2}\right)$ & $23.97 \pm 2.73$ & $26.55 \pm 5.15$ & $23.16 \pm 3.62$ & 0.017 \\
WHR & $0.76 \pm 0.06$ & $0.79 \pm 0.07$ & $0.75 \pm 0.04$ & 0.033 \\
FGS & $5.05 \pm 3.80$ & $9.00 \pm 4.84$ & $7.09 \pm 4.07$ & 0.005 \\
\hline
\end{tabular}

BMI: Body mass index, WHR: Waist/Hip ratio, FGS: Ferriman-Gallwey score 
Table 2. The metabolic characteristics of groups

\begin{tabular}{lllll}
\hline & Group 1 $(\mathrm{n}=22)$ & Group 2 $(\mathrm{n}=41)$ & Group 3 $(\mathrm{n}=22)$ & P value \\
\hline HOMA-IR & $4,08 \pm 2,73$ & $3,09 \pm 1,56$ & $3,58 \pm 1,04$ & 0.007 \\
OGTT $(\mathrm{mg} / \mathrm{DI})$ & $102.18 \pm 22.07$ & $127.32 \pm 30.04$ & $97.55 \pm 25.28$ & 0.001 \\
\hline
\end{tabular}

HOMA-IR: insulin resistance by the homeostasis model assessment, OGTT: oral glucose tolerance test 120 . minute value

Table 3. The hormonal characteristics and IL-6 levels of groups

\begin{tabular}{lllll}
\hline & Group 1 $(\mathrm{n}=22)$ & Group 2 $(\mathrm{n}=41)$ & Group 3 $(\mathrm{n}=22)$ & P value \\
\hline FSH $(\mathrm{mlU} / \mathrm{L})$ & $5.23 \pm 1.77$ & $5.88 \pm 2.66$ & $6.28 \pm 4.01$ & 0.664 \\
$\mathrm{E}_{2}(\mathrm{pg} / \mathrm{L})$ & $94.93 \pm 79.66$ & $88.11 \pm 121.64$ & $107.54 \pm 120.84$ & 0.902 \\
$\mathrm{LH}(\mathrm{mlU} / \mathrm{L})$ & $10.80 \pm 9.83$ & $11.95 \pm 9.38$ & $9.94 \pm 5.94$ & 0.318 \\
TSH $(\mathrm{mlU} / \mathrm{L})$ & $2.80 \pm 1.60$ & $2.01 \pm 0.78$ & $2.24 \pm 1.09$ & 0.121 \\
$\mathrm{FT}_{3}(\mathrm{pg} / \mathrm{mL})$ & $3.25 \pm 0.69$ & $3.07 \pm 0.97$ & $2.98 \pm 0.55$ & 0.249 \\
$\mathrm{FT}_{4}(\mathrm{pmol} / \mathrm{L})$ & $16.31 \pm 2.19$ & $18.30 \pm 4.53$ & $16.57 \pm 2.79$ & 0.265 \\
DHEA-S $(\mathrm{ug} / \mathrm{dL})$ & $285.48 \pm 113.71$ & $280.87 \pm 82.98$ & $265.88 \pm 97.37$ & 0.667 \\
SHBG $(\mathrm{nmol} / \mathrm{L})$ & $29.78 \pm 21.31$ & $24.08 \pm 16.53$ & $28.87 \pm 16.15$ & 0.339 \\
FTes $(\mathrm{pg} / \mathrm{mL})$ & $3.30 \pm 3.07$ & $3.41 \pm 2.30$ & $3.18 \pm 2.79$ & 0.411 \\
TTes $(\mathrm{ng} / \mathrm{mL})$ & $0.62 \pm 0.27$ & $0.73 \pm 0.24$ & $0.69 \pm 0.41$ & 0.195 \\
Prog-21 $(\mathrm{ng} / \mathrm{mL})$ & $5.20 \pm 6.31$ & $5.82 \pm 6.01$ & $5.36 \pm 5.35$ & 0.752 \\
As $(\mathrm{ng} / \mathrm{mL})$ & $4.35 \pm 1.60$ & $4.05 \pm 1.51$ & $3.57 \pm 1.12$ & 0.205 \\
IL-6 $(\mathrm{pg} / \mathrm{mL})$ & $14.65 \pm 6.18$ & $16.22 \pm 6.55$ & $14.53 \pm 7.32$ & 0.667 \\
\hline
\end{tabular}

$\mathrm{FSH}$ : , follicle stimulating hormone, $\mathrm{E}_{2}$ : estradiol,LH: luteinizing hormone, $\mathrm{FT}_{3}$ : free triiodothyronine, $\mathrm{FT}_{4}$ : free thyroxine, DHEA-S: dihydroepiandesterone sulphate, SHBG : sex hormone binding globuline, FTes: free testosterone, TTes: total testosterone, Prog-21: progesterone on 21th day of menstrual cycle, As: Androstenedion, IL-6: interleukin 6.

\section{DISCUSSION}

Polycystic ovary syndrome is one of the most common endocrine disorders in humans. In fact, most women with PCOS exhibit features of metabolic syndrome. ${ }^{17}$ The diagnosis of PCO is ultrasound examination of the ovaries with the presence of multiple peripheral small cysts. There is still debate about whether there has to be more than 10-12 cysts and whether both ovaries have to be effected. According to Rotterdam consensus criteria commonly used in clinical practice, two of the following three must be fulfilled for the diagnosis of PCOS: polycystic ovaries (12 or more follicles in each ovary, each follicle measuring $2-9 \mathrm{~mm}$ in diameter and/ or ovarian volume $>10 \mathrm{~mL}$, one polycystic ovary is sufficient for the diagnosis), oligo-/anovulation; clinically diagnosed as oligo-/amenorrhea and hyperandrogenism. ${ }^{1}$
In this study, we analyzed the biochemical parameters and IL- 6 according to the ovarian morphology in PCOS. Although there was not statistically a meaningful connection between the study groups, high levels at IL-6 were established in all groups. The process of an inflammatory response the invading pathogens or damaging insults is of critical importance to the homeostasis of the human body. Puder et al. demonstrated that the increase in low grade chronic inflammation and in insulin resistance in women with PCOS is associated with central fat excess. Independently of each other, both total body fat as well as central fat excess has a major impact on serum levels of inflammatory mediators, on the WBC, and on estimates of insulin resistance. ${ }^{18}$ There is a balance of IL-6 at inflammation, immunity, bone metabolism, natural development, reproduction and homeostasis. On the other hand, when the balance of IL- 6 is damaged, the following pathologies are occurred as chronic inflammation, 
autoimmunity, osteoporosis, atherosclerosis, rheumatoid arthritis, breast/prostate cancer, cardiovascular disease, diabetes and atopy..$^{19}$ This inflammatory marker may be involved in the pathogenesis of the insulin resistance syndrome ${ }^{20}$ and high levels of IL-6 become a risk for diabetes, atherosclerosis and cardiovascular disease..$^{21,22}$ In the multi-ethnic study of atherosclerosis, psychosocial factors were positively associated with inflammatory markers including IL-6 concentrations, but these associations were reduced by $45-100 \%$ after adjustment for BMI and diabetes. ${ }^{23}$ As a result, it is believed that chronic inflammation is a predisposing factor for CVD. It has been correlated with obesity and insulin resistance but not hyperandrogenemia in PCOS. ${ }^{24}$

In the presence of PCOS, there are many problems for the women. Hirsutism, acne, or alopecia is short-term problem, long-term effects are noninsulin-dependent diabetes mellitus, cardiovascular diseases (dyslipidemia, hypertension, vascular disease, ovarian dysfunction). ${ }^{25}$ Ferriman Galwey Score was determined significantly low at the group 1 of no ovarian pathology $(p=0.005)$. Hirsutism increased with the level of ovarian pathology. The incidence of non-insulin-dependent diabetes mellitus is found six-fold at ${ }^{22-31}$ aged-women. Especially obesity is well recognized as a risk factor and is a common association with PCOS; diabetes is found a contributory cause for death 3, 6 times more commonly than expected. There were statistically significant connection between BMI and WHR (waisthip ratio) at group 2 ( $p=0.017,0.033$ respectively). HOMA-IR was high level in all groups but that it was statistically found least in group 2 than the others was determined $(p=0.007)$. The patients with or without ovarian morphology change the risk of type 2 diabetes does not change.

Many of the biochemical disturbances such as insulin resistance and hyperandrogenism and the resultant unfavorable changes in blood lipids, which are associated with PCOS, are recognized risk factors. PCOS may contribute to the risk of developing cardiovascular disease. Hyperinsulinemia has been found to be associated with a higher risk of cardiovascular disease. ${ }^{26}$ The increased concentrations of inflammatory markers cluster with cardiovascular risk factors such as dyslipidemia, glucose intolerance and type 2 diabetes, hypertension, and obesity. Chronic low-grade inflammation has been proposed to play a role in the pathogenesis of insulin resistance and the metabolic syndrome. ${ }^{27}$ Chronic inflammation could be involved in the development of metabolic syndrome and cardiovascular disease. Serum markers of chronic inflammation together with insulin resistance are increasingly being considered as cardiovascular risk factors. Atherogenesis is associated with chronic local inflammation, and the inflammatory process could result in the release of cytokines into the circulation such as TNF- $\alpha$ or IL-6. ${ }^{28}$

In conclusion, we could not find any difference between them in this clinical study, when we studied on clinic, hormonal and inflammatory markers according to the presence of the ovarian pathologies. PCOS had the same level of risk from CVS and diabetes mellitus for different ovarian morphology. IL-6 higher patients may much more risk of CVS and diabetes mellitus than the others. This situation might be said because of the findings both BMI and WHR for ovarian morphology difference at PCOS.

\section{REFERENCES}

1. The Rotterdam ESHRE/ASRM-Sponsored PCOS Consensus Workshop Group. Revised 2003 consensus on diagnostic criteria and long-term health risks related to polycystic ovary syndrome. Fertil Steril 2004;81(1).19-25.

2. Franks S. Polycystic ovary syndrome. N Engl J Med 1995;333(13):853-61.

3. Yildiz BO, Haznedaroğlu IC, Kirazli S, Bayraktar M. Global fibrinolytic capacity is decreased in polycystic ovary syndrome, suggesting a prothrombotic state. J Clin Endocrinol Metab 2002;87(8):3871-5.

4. Orio F, Vuolo L, Palomba S, Lombardi G, Colao A. Metabolic and cardiovascular consequences of polycystic ovary syndrome. Minerva Ginecol 2008;60(1):39-51.

5. Bray GA. Medical consequences of obesity. J Clin Endocrinol Metab 2004;89(6):2583-9.

6. Diamanti-Kandarakis E, Paterakis T, Alexandraki K, et al. Indices of low-grade chronic inflammation in polycystic ovary syndrome and the beneficial effect of metformin. Hum Reprod 2006;21(6):1426-31.

7. Moscovitz H, Shofer F, Mignott H, Behrman A, Kilpatrick L. Plasma cytokine determinations in emergency department patients as a predictor of bacteremia and infectious disease severity. Crit Care Med 1994;22(7):1102-7.

8. Villuendas G, San Millán JL, Sancho J, Escobar-Morreale HF. The -597 G-->A and -174 G-->C polymorphisms in the promoter of the IL-6 gene are associated with hyperandrogenism. J Clin Endocrinol Metab 2002;87(3):1134-41.

9. Hotamisligil GS, Peraldi P, Budavari A, Ellis R, White MF, Spiegelman BM. IRS-1-mediated inhibition of insulin receptor tyrosine kinase activity in TNF-alpha- and obesity-induced insulin resistance. Science 1996;271(5249):665-8.

10. Taylor AE, McCourt B, Martin KA, et al. Determinants of abnormal gonadotropin secretion in clinically de- 
fined women with polycystic ovary syndrome. J Clin Endocrinol Metab 1997;82(7):2248-56.

11. Legro RS, Chiu P, Kunselman AR, Bentley CM, Dodson WC, Dunaif A. Polycystic ovaries are common in women with hyperandrogenic chronic anovulation but do not predict metabolic or reproductive phenotype. J Clin Endocrinol Metab 2005;90(5):2571-9.

12. Birdsall MA, Farquhar CM. Polycystic ovaries in pre and post-menopausal women. Clin Endocrinol (Oxf) 1996;44(3):269-76.

13. Ferriman D, Gallwey JD. Clinical assessment of body hair growth in women. J Clin Endocrinol Metab 1961;21:1440-7.

14. Endl J, Otto H, Jung G, et al. Identification of naturally processed $T$ cell epitopes from glutamic acid decarboxylase presented in the context of HLA-DR alleles by $T$ lymphocytes of recent onset IDDM patients. J Clin Invest 1997;99(10):2405-15.

15. Matthews DR, Hosker JP, Rudenski AS, Naylor BA, Treacher DF, Turner RC. Homeostasis model assessment: insulin resistance and beta-cell function from fasting plasma glucose and insulin concentrations in man. Diabetologia 1985;28(7):412-9.

16. Genuth S, Alberti KG, Bennett P, et al. Expert Committee on the Diagnosis and Classification of Diabetes Mellitus. Follow-up report on the diagnosis of diabetes mellitus. Diabetes Care 2003;26(11):3160-7.

17. Knochenhauer ES, Key TJ, Kahsar-Miller M, Waggoner W, Boots LR, Azziz R. Prevalence of the polycystic ovary syndrome in unselected black and white women of the southeastern United States: a prospective study. J Clin Endocrinol Metab 1998;83(9):3078-82.

18. Puder JJ, Varga S, Kraenzlin M, De Geyter C, Keller U, Müller B. Central fat excess in polycystic ovary syndrome: relation to low-grade inflammation and insulin resistance. J Clin Endocrinol Metab 2005;90(11):601421.
19. Dijsselbloem N, Vanden Berghe W, De Naeyer A, Haegeman G. Soy isoflavone phyto-pharmaceuticals in interleukin-6 affections. Multi-purpose nutraceuticals at the crossroad of hormone replacement, anticancer and anti-inflammatory therapy. Biochem Pharmacol 2004;68(6):1171-85.

20. Rosenson RS, Tangney CC, Levine DM, Parker TS, Gordon BR. Elevated soluble tumor necrosis factor receptor levels in non-obese adults with the atherogenic dyslipoproteinemia. Atherosclerosis 2004;177(1):7781.

21. Frishman WH. Biologic markers as predictors of cardiovascular disease. Am J Med 1998;104(6A):18S$27 S$.

22. Fernández-Real JM, Ricart W. Insulin resistance and chronic cardiovascular inflammatory syndrome. Endocr Rev 2003;24(3):278-301.

23. Ranjit N, Diez-Roux AV, Shea S, et al. Psychosocial factors and inflammation in the multi-ethnic study of atherosclerosis. Arch Intern Med 2007;167(2):174-81.

24. Kelly CC, Lyall H, Petrie JR, Gould GW, Connell JM, Sattar N. Low grade chronic inflammation in women with polycystic ovarian syndrome. J Clin Endocrinol Metab 2001;86(6):2453-5.

25. Kovacs GT. Polycystic ovarian disease: an overview. Rev Gynaecol Pract 2004;2(4):97-104.

26. Mather KJ, Kwan F, Corenblum B. Hyperinsulinemia in polycystic ovary syndrome correlates with increased cardiovascular risk independent of obesity. Fertil Steril 2000;73(1):150-6.

27. Fernández-Real JM, Ricart W. Insulin resistance and inflammation in an evolutionary perspective: the contribution of cytokine genotype/phenotype to thriftiness. Diabetologia 1999;42(11):1367-74.

28. Yudkin JS, Kumari M, Humphries SE, Mohamed-Ali V. Inflammation, obesity, stress and coronary heart disease: is interleukin-6 the link? Atherosclerosis 2000;148(2):209-14. 